\title{
Identifying Risk of Dementia Using Subjective Cognitive Decline (Scd) Instruments Among Elderly in Bandung, Indonesia
}

\author{
Lia Juniarni1, Risma Pujianti², and Masdum $\|$ brahim ${ }^{3}$ \\ ${ }^{1}$ Program Pendidikan Ners, Bidang Keilmuan Keperawatan Jiwa, Sekolah Tinggi IImu \\ Keperawatan PPNI Jawa Barat, Bandung, Indonesia \\ ${ }^{2}$ Program Vokasi Keperawatan, Bidang Keilmuan Keperawatan Jiwa, Sekolah Tinggi IImu \\ Keperawatan PPNI Jawa Barat, Bandung, Indonesia
}

ORCID:

Lia Juniarni: https://orcid.org/0000-0001-7336-0152

\section{Abstract}

Cognitive decline in the elderly is often referred to as dementia. Dementia is an effect of the aging process, which impacts the brain function. The subjective cognitive decline happens when a person's cognitive perceptions experience decline but remain within parameters considered normal. A screening process for this condition is one of the efforts which can improve welfare services for the elderly. Subjective Cognitive Decline (SCD) is cognitive self-reports that assess subjective cognitive impairment abilities by prompting the recall of frequently experienced events. SCD has a double function, as an instrument for both early detection and the prevention of disease. This study aims to identify the risk of dementia using a Subjective Cognitive Decline (SCD) instrument. This research was conducted using a quantitative descriptive method with a cross-sectional approach. 187 elderly were taken as the sample by consecutive sampling methods, and data were analyzed using univariate analysis. This study showed that most of the respondents have a poor subjective cognitive decline, with $54.0 \%$. The domains that have the most cognitive decline were the orientation with $78.1 \%, 76.5 \%$ of executive function, $68.4 \%$ of memory, and $59.4 \%$ of language. Demographic data associated with subjective cognitive decline showed poorly in female gender with $55.6 \%$, age> 90 years with $55.3 \%$, high school education with $70.4 \%$, married status with $57.1 \%$, and unemployed with $53.2 \%$. This study concludes that the results of SCD with poor subjective cognitive decline have a risk of developing dementia.

Keywords: Dementia, elderly, subjective cognitive decline

\section{Introduction}

Indonesia is a country with a high elderly number, Indonesia is in the top five globally, and those numbersare predicted to increase compared to the adult population in 2050- 
elderliesin Indonesia reached 18,781 million, and it is estimated that in 2025 the number will increase to reach 36 million (1). This number shows that Indonesia has begun to enter the era of an aging population. The increaseinthe number of elderlies is elderliesa challenge, especially for the health sector. Moreover,it can come with degenerative diseases, non-communicable diseases, and other mental health problems (2).

The aging process in the elderly generally starts to appear at 45 years old and will cause severe problems at around 60 years old(3). One of the health problems associated with the aging process's symptoms is a decline in cognitive function(4). Cognitive decline with the symptoms of forgetfulness or often called dementia. Dementia is an effect of aging, which has an impact on the destruction of brain function. It is estimated that about $39 \%$ of people aged 50-59 years experienced fail to remember things and an increase of $85 \%$ when the elderly are over 80 years old(5). Mild Cognitive Impairment (MCl) is an intermediate symptom between age-related memory and cognitive impairment (Age-Associated Memory Impairment / AAMI) and dementia (6).

High cognitive decline has a risk of developing dementia, where dementia is a collection of symptoms that refer to decreased brain function, including reduced memory, impaired thinking,behavior processes, andchanges in mental or emotional conditions. Alzheimer's dementia is the most common dementia case, with about $60-80 \%$ of Alzheimer's disease isa neurodegenerative disorder (7). This shows that cognitive decline is a normal part of the aging process of the elderly who will experience retardation even though the intelligence will be stable or physically will decline.

The screening process is one of the efforts to improve welfare services for the elderly. By the screening, early detection can be held, and early treatment can be given. Then it might be resulted as one of the treatments to slow the severity of dementia. Various screening tools are used, but Subjective Cognitive Decline (SCD) has a double function, both as an instrument for early detection and disease prevention. SCD is targeted at selfreported memory with subjective perceived cognitive changes because the memory domains are most commonly experienced as $\mathrm{MCl}$ disorders and develop dementia. SCD is also used as an early symptom test before psychometric tests to distinguish that cognitive decline is frail. The application of SCD also be used for the elderly who have limitations in reading and writing, and its application is easy to accept, low cost, and practical.Therefore, this study aimed atusing a Subjective Cognitive Decline (SCD) instrument as tools to identify the risk of dementia. Also, to analyze more depth in several domains: memory, language, orientation, attention, executive function, and visuospatial. 


\section{Methods}

\subsection{Study Design}

This study used a descriptive quantitative design with a cross-sectional approach to identify cognitive decline and each domain-this study conducted in Bandung, Indonesia.

\subsection{Sample}

The target population in this study was the elderly in Bandung. Consecutive sampling used to recruit a sample with the inclusioncriteria of the elderly was 60 years or older and able to communicate. Elderly with comorbidities could interfere with the measurement, the elderly with mental disorders, the elderly with hearing loss, and the elderly who could not speak were excluded.

Estimation of sample size was calculated via G-Power Software Version 3.0.10 using exact test, statitical test proportion difference from constant (binomial test, one sample case) with assumption $\alpha=0,05$, medium effect size $=0,15$, power level $=0,9$ and constant proportion $=0,65$. A sample size of 187 was needed with $10 \%$ attrition rate.

\subsection{Instrument}

Two instrumentsin the Indonesian version were used in this study. First is the demographic questionnaire, which included age, sex, level of education, and employment status. The second questionnaire is Subjective Cognitive Decline (SCD). The SCD is a self-reported cognitive status produced by the Subjective Cognitive-Initiative (SCD-I) Working Group that included researchers for Alzheimer's Disease and SCD's special interests, launched in October 2012. SCD, used as a feature in detecting and preventing diseases that will develop into dementia, contains 30 questions with 6 domains: memory, attention, language, visuospatial, executive function, and orientation. The instrument is obtained from HHS (Department of Human Health and Service) Public Access. Permission to usethe questionnaire was obtained from a member of the SCD-I through email. The translation process was conducted with experts, and Cronbach's alpha of this study showed 0.809 . 


\subsection{Data Collection}

Data were collected by the researcher after obtained approval from the Institutional Review Board (IRB) of STIKEP PPNI Jawa Barat and get permission from the vice of Primary Health Care Center at Bandung. The researcher and cadre approached the participants by visited the elderly's home and explained study purpose, ethical considerations suchas Beneficence dan nonmaleficence, Anonymity, Veracity, and Justice, also described the content of the questionnaire. After getting consent, the researcher asked the participant to complete the SCD (Subjective Cognitive Decline). After completing the questionnaire, the participant returned the questionnaire, and the researcher rechecked the questionnaire sheets' completeness.

\subsection{Data Analysis}

Data analysis was performed using IBM SPSS version 25 for Windows. To measure normality distribution, Kolmogorov-Smirnovtest was used, statistic $=0,104 ; \mathrm{df}=82$ dan with significant value $0,028<0,05$. Univariate analysis was used to describe demographic participants and SCD variable. Data were showed using distribution frequency and percentage for categoric level, then mean and standard deviation for continuous level.

\section{Result}

The number of participants in this study is 187. Based on table 1,the average age of participant are $79.09 \pm 9.630$ years old; $49.7 \%(n=93)$ in elementary school level of education; 68.4\% ( $n=128)$ were unemployed and $82.4 \%(n=154)$ were married.

Based on the data in Table 2 showed that most of the respondents have a poor subjective cognitive decline; $54.0 \%$. Based on table 3 , the domains that have the most poorly cognitive decline were the Orientation domain of $78.1 \%, 76.5 \%$ of Executive Function, $68.4 \%$ of Memory and $59.4 \%$ of Language. Demographic data associated with subjective cognitive decline based on table 4 showed poorly in female gender with $55.6 \%$, age $>90$ years with $55.3 \%$, high school education with $70.4 \%$, married status with $57.1 \%$, and unemployed $53.2 \%$. 
TABLE 1: Demographic Data $(n=187)$

\begin{tabular}{|l|l|c|c|}
\hline Variable & Categoric & N & Percentage (\%) \\
\hline Gender & Female & 117 & $62.6 \%$ \\
\hline Level of Education & Male & 70 & $37.4 \%$ \\
\hline & Uneducated & 33 & $17.6 \%$ \\
\hline & Elementary School & 93 & $49.7 \%$ \\
\hline & Junior High School & 29 & $15.5 \%$ \\
\hline \multirow{2}{*}{ Employment Status } & Senior High School & 27 & $14.4 \%$ \\
\hline & University & 5 & $2.7 \%$ \\
\hline Marital Status & Unemployed & 128 & $68.4 \%$ \\
\hline & Employed & 59 & $31,6 \%$ \\
\hline Variable & Married & 154 & $82.4 \%$ \\
\hline Age & Widowed & 33 & $17.6 \%$ \\
\hline
\end{tabular}

TABLE 2: Subjective Cognitive Decline ( $n=187)$

\begin{tabular}{|l|c|c|}
\hline Categories & Frequency & Percentage (\%) \\
\hline Poor & 101 & $54,0 \%$ \\
\hline Well & 86 & $46,0 \%$ \\
\hline Total & 187 & $100 \%$ \\
\hline
\end{tabular}

\section{Discussion}

This study shows more than half of the elderly experienced poor subjective cognitive decline (54.0\%). Poor subjective cognitive decline is indicated by a cognitive response that the elderly often forget something but remain considered normal, difficulty in making decisions, frequent nightmares, confusion, or reveal and realize physiological symptoms (8).The severity of subjective cognitive decline symptoms is associated with dementia, especially anxiety and depression(9). Patients with mild cognitive impairment have two extreme possibilities: either high risk of Alzheimer's disease or a partial return to normal cognitive function. Mild cognitive decline is not a definitive diagnosis of neurodegenerative disease(10). This result is that cognitive decline in the elderly can be seen as a result of the aging process changes, and the reaction to these changes is different in each person and depends on the individual(11).

Several factors can affect cognitive function changes in the elderly, including age; the results showed a poor subjective cognitive decline at age $>90$ years. This can happendue to an increase in the number of tissue cells, which leads to aging. The aging process will decrease the nervous system's function, such as the shrinking of the brain 
TABLE 3: Frequency Distribution of Subjective Cognitive Decline based on Domain $(n=187)$

\begin{tabular}{l|c|c|}
\hline $\begin{array}{l}\text { Characteristic of } \\
\text { Subjective Cognitive } \\
\text { Decline }\end{array}$ & Frequency & Percentage (\%) \\
\hline $\begin{array}{l}\text { Memory } \\
\text { Poor }\end{array}$ & 128 & \\
\hline Well & 59 & $68.4 \%$ \\
\hline Orientation & & $31.6 \%$ \\
\hline Poor & 146 & \\
\hline Well & 41 & $78.1 \%$ \\
\hline Visuospatial & & $21.9 \%$ \\
\hline Poor & 83 & \\
\hline Well & 104 & $44.4 \%$ \\
\hline Language & 111 & $55.6 \%$ \\
\hline Poor & 76 & $59.4 \%$ \\
\hline Well & & $40.6 \%$ \\
\hline Executive Function & 143 & \\
\hline Poor & 44 & $76.5 \%$ \\
\hline Well & & $23.5 \%$ \\
\hline Attention & 710 & \\
\hline Poor & & $58,8 \%$ \\
\hline Well & & $4.2 \%$ \\
\hline
\end{tabular}

and biochemical changes in the CNS, causinga decline in cognitive function(12).Another factor is gender; the results showed that the subjective cognitive decline was poor in females, although the results showed no significant difference. This result is similar(13, 14), which states that men are more at risk of experiencing cognitive changes at an earlier age than women. Still, women are more at risk of experiencing cognitive decline at an advanced age. This event can happen due to the role of the sex hormone oestrogenthat canchange cognitive function. Oestrogen receptors are found in the brain areas that play a role in maintaining brain function, such as learning and memory functions.

Other factors, such as education level, showed that the elderly with senior high school hadthe highest cognitive decline. This result confirmed (15)that education can stimulate mental activity, which is useful for neurochemistry and the influence of brain structures. According to the synaptic reserve hypothesis theory, people with higher education have more brain synapses than people with lower education. When the synapse is destruction due to Alzheimer's disease, another synapse will replace the damaged one.

In this study, each domain of subjective cognitive decline was included in poor categoric. This is in line with(16), which states that a person experiences subjective cognitive decline when one of the cognitive domains is often felt. It can lead to a 
TABLE 4: Frequency Distribution of Subjective Cognitive Decline based on Demographic Data ( $\mathrm{n}=187$ )

\begin{tabular}{|c|c|c|c|c|}
\hline \multirow[t]{2}{*}{ Variable } & \multirow[t]{2}{*}{ Total n (\%) } & \multicolumn{2}{|c|}{ Subjective Cognitive Decline } & \multirow[t]{2}{*}{ P-value } \\
\hline & & Poor & Well & \\
\hline \multicolumn{5}{|l|}{ Gender } \\
\hline Female & $117(62.6)$ & 65 (55.6\%) & 52 (44.4\%) & 0.582 \\
\hline Male & $70(37.4)$ & 36 (51.4\%) & 34 (48.6\%) & \\
\hline Age(Mean \pm SD) & $79.09 \pm 9.630$ & & & 0.043 \\
\hline$<90$ years old & $140(74.9)$ & 75 (53.6\%) & 65 (46.4\%) & \\
\hline$>90$ years old & $47(25.1)$ & $26(55.3 \%)$ & $21(44.7 \%)$ & \\
\hline $\begin{array}{l}\text { Level of } \\
\text { Education }\end{array}$ & & & & 0.86 \\
\hline Uneducated & $33(17.6)$ & $21(63.6 \%)$ & $12(36.4 \%)$ & \\
\hline $\begin{array}{l}\text { Elementary } \\
\text { School }\end{array}$ & $93(49.7)$ & 41 (44.1\%) & 52 (55.9\%) & \\
\hline $\begin{array}{l}\text { Junior High } \\
\text { School }\end{array}$ & $29(15.5)$ & 17 (58.6\%) & 12 (41.4\%) & \\
\hline $\begin{array}{l}\text { Senior High } \\
\text { School }\end{array}$ & $27(14.4)$ & 19 (70.4\%) & 8 (29.6\%) & \\
\hline University & $5(2.7)$ & $3(60.0 \%)$ & 2 (40.0\%) & \\
\hline Marital Status & & & & 0.63 \\
\hline Married & $154(82.4)$ & $88(57.1 \%)$ & 66 (42.9\%) & \\
\hline Widowed & $33(17.6)$ & $13(39.4 \%)$ & $20(60.6 \%)$ & \\
\hline $\begin{array}{l}\text { Employment } \\
\text { Status }\end{array}$ & & & & 0.720 \\
\hline Unemployed & $128(68.4)$ & $68(53.2 \%)$ & 60 (46.9\%) & \\
\hline Employed & 59 (31.9) & 33 (55.9) & 26 (44.1\%) & \\
\hline
\end{tabular}

declinein objective cognitive performance and may demonstrate beliefs about cognitive decline with the aging process.

The analysis based on domain showed that orientation, executive function, memory, and language have the highest percentage. The orientation domain is explained by short-term memory, which is the individual's ability to assess new memories or remember names concerning people. In this study, orientation was measured by askingthe elderly to reference people, such as asking their family member names, close friends, or remembering some relatives. Orientation towards people shows "overlearned" information. The elderly who fail to remember or say their name reflects the negativism, distractions, hearing loss, or language acceptance disorder of their own (17).

Similar tothe orientation domain, the executive function domain resulted in poor function. The elderly felt some symptoms like failure to remember planned activities. Suchthey forgot to do the following activity. Another symptom is they sure about starting to forget somethings. One study (18)states that to perform executive functions, the 
multifocal neuronal system needs to integrate with the cortex of the frontal lobe, basal ganglion, and thalamus. Impaired executive function is mostly caused by metabolic disorders, intoxication, cerebral infections, head trauma, brain tumors, frontal lobe lesions, and degeneration, damaging the nervous system.

The language domain also showed a poor result. Thisstudy's results are consistent with the previous research (19). In the presence of language disorders,the elderly will find it hard to express and understand writing and pronounce words.Wernicke'sbrain areachanges will show receptive aphasia movements, which are not audible or difficult to understand. Damage of Wernicke's area will cause obstacles to understanding both in speaking and writing.

The frequency distribution of the memory domain resulted in most of the respondents having poor memory capability. The ability to remember means being able to save and bring back something that has been experienced.However, it does not mean that everything experienced will be completely stored in memory because memory has a limited ability(20).In this study, the perceptions were measured by asking the elderly to remember things that had happened or had been done recently.If the elderly is unable to remember, the information will be lost from the system memory. However, it is different from long-term memory,remembering the past, and using the information to be used today. This is shown by how the elderly remember the past few years or a few days ago, then disclosed (21).

The elderly will experience a drastic physical decline and affect their cognitive function, especially their intelligence level and memory. The ability to remember is related to remembering past events and the elderly's intelligence ability of the elderly in calculating things such as counting and the decline in the ability of the elderly to carry out their activities (22).

\section{Conclusion}

The description of subjective cognitive decline in this study was poor. It can lead tothe risk of developing dementia. The most poorly subjective cognitive declinedomain was orientation, executive function, language, and memory. Based on those results, health workers are expected to do preventive measures in at-risk populations, suchas femalesaged over 60, low educated elderly, and complex environments. As well as being able to apply the initial screening of dementia using the SCD (Subjective Cognitive Decline) instrument. 


\section{References}

[1] Depkes RI. (2015). Pelayanan dan Peningkatan Kesehatan Usia Lanjut. Retrieved January 22, 2019 from http://www.depkes.go.id/article/view/15052700010/ pelayanan-dan-peningkata-kesehatan-usia-lanjut.html.

[2] Kemenkes RI. (2018). Populasi Lansia Diperkirakan Terus Meningkat Hingga Tahun 2020 Retrieved January 23, 2019 from www.depkes.go.id.

[3] Pudjiastuti, S. and Utomo, B. (2003). Fisioterapi Pada Lansia. Jakarta: EGC.

[4] Lumbatobing, S. (2006). Kecerdasan Pada Usia Lanjut dan Demensia. Jakarta: Balai Penerbit FKUI.

[5] Wreksoatmodjo, B. R. (2012). Hubungan Social Engagement dengan Fungsi Kognitif. Cermin Dunia Kedokeran (CDK),190, Jakarta, p. 39.

[6] Ekasari, M. F., Riasmini, N. M. and Hartini, T. (2018). Meningkatkan Kualitas Hidup lansia Konsep Dan Berbagai Intervensi. Malang: Wineka Media.

[7] Anam, O., et al. (2015). Diagnosis dan Penatalaksanaan Demensia. Retrieved from http://www.perdossi.or.id.

[8] Zaini, M. (2019). Asuhan Keperawatan Jiwa Masalah Psikososial Di Pelayanan Klinis Dan Komunitas. Yogyakarta: Deepublish.

[9] Reisberg, B., et al. (2008). The Pre - Mild Cognitive Impairment, Subjective Cognitive Impairment Stage of Alzheimer's Disease. Alzheimer's \& Dementia. Vol 4 Issue 1, pp. 98-108.

[10] Rosenberg, P. B., Johnston, D. and Lyketsos, C. G. (2006). A Clinical Approach to Mild Cognitive Impairment. Treatment in Psychiatry. Am J Psychiatry 163:11

[11] Supriadi, S. (2015). Lanjut Usia dan Permasalahannya (vol. 10). Jurnal PPKn dan Hukum. Sumatera Barat.

[12] Sundariyati, I. G. A. H., Ratep, N. and Westa, W. (2014). Gambaran Faktor-Faktor Yang Mempengaruhi Status Kognitif Pada Lansia Di Wilayah Kerja Puskesmas Factors That Affect The Cognitive States In Elderly. E-Jurnal Medika Udayana. Vol 4, 1.

[13] Maryati, H., Bhakti, D. S. and Dwiningtyas, M. (2013). Description Of Cognitive Function in Elderly Upt Institution In Elderly Mojopahit. Jambang: STIKES Pemkab Jambang.

[14] Myers, J. S. (2008). Factors Associated with Changing Cognitive Function in Older Adults: Implications for Nursing Rehabilitation. Rehabilitation Nursing, May-Jun 33(3):117-23. 
[15] Izzah, A. (2014). Hubungan Aktivitas Fisik Dengan Fungsi Kognitif Lansia Pada Lansia Usia 60-69 Tahun Di Kelurahan Purwantoro. Universitas Muhammadiyah Malang, Vol 10(2) Pp. 88-93.

[16] Vlachos, G. S., et al. (2019). Prevalence and Determinants of Subjective Cognitive Decline in a Representative Greek Elderly Population. Int Geriatr Psychiatry. Jun;34(6): 846-854.

[17] Dayamaes, R. (2013). Gambaran Fungsi Kognitif Klien Usia Lanjut di Posbindu Rosella Legoso Wilayah Kerja Puskesmas Ciputat Timur Tangerang Selatan. IPB Scientfic Repositry. UIN Syarif Hidayatullah Jakarta (UIN-JKT-IR), issue 27.

[18] Dahlan, P. (2003). Pemeriksaan Neuropsikologi Pada Demensia. Berk Neurosains, issue 4 , pp. 17-22.

[19] Fitriani, R., Saraswati, L. G. I. and Suardana, I. W. (2014). Status Kognitif Dan Kualitas Hidup Lansia. Jurusan Keperawatan Politeknik Kesehatan Denpasar(20)

[20] Ahmadi, A. (2009). Psikologi Umum. Jakarta: Rineka Cipta.

[21] Bhinnety, M. (2015). Struktur dan Ptoses Memori (vol. 16). Buletin Psikologi. Yogyakarta.

[22] Aini, D. N. and Puspitasari, W. (2016). Hubungan Fungsi Kognitif dengan Kualitas Hidup pada Lansia di Kelurahan Barusari Kecamatan Semarang Selatan. Media Neliti, Issue 7, pp. 6-12. 